Louisiana State University

LSU Digital Commons

$1-1-2014$

\title{
Myo-Inositol and phytate are toxic to Formosan subterranean termites (Isoptera: Rhinotermitidae)
}

\author{
Lucas Veillon \\ Louisiana State University \\ Jared Bourgeois \\ Louisiana State University \\ Amanda Leblanc \\ Louisiana State University \\ Gregg Henderson \\ LSU Agricultural Center \\ Brian D. Marx \\ Louisiana State University
}

See next page for additional authors

Follow this and additional works at: https://digitalcommons.Isu.edu/biosci_pubs

\section{Recommended Citation}

Veillon, L., Bourgeois, J., Leblanc, A., Henderson, G., Marx, B., Muniruzzaman, S., \& Laine, R. (2014). MyoInositol and phytate are toxic to Formosan subterranean termites (Isoptera: Rhinotermitidae). Journal of Economic Entomology, 107 (5), 1800-1812. https://doi.org/10.1603/EC13323

This Article is brought to you for free and open access by the Department of Biological Sciences at LSU Digital Commons. It has been accepted for inclusion in Faculty Publications by an authorized administrator of LSU Digital Commons. For more information, please contact ir@lsu.edu. 


\section{Authors}

Lucas Veillon, Jared Bourgeois, Amanda Leblanc, Gregg Henderson, Brian D. Marx, Syed Muniruzzaman, and Roger A. Laine 


\title{
myo-Inositol and Phytate Are Toxic to Formosan Subterranean Termites (Isoptera: Rhinotermitidae)
}

\author{
LUCAS VEILLON, ${ }^{1}$ JARED BOURGEOIS,${ }^{1}$ AMANDA LEBLANC,${ }^{1}$ GREGG HENDERSON, ${ }^{2}$ \\ BRIAN D. MARX, ${ }^{3}$ SYED MUNIRUZZAMAN,${ }^{4}$ AND ROGER A. LAINE ${ }^{1,5,6}$
}

\begin{abstract}
J. Econ. Entomol. 107(5): 1800-1812 (2014); DOI: http://dx.doi.org/10.1603/EC13323
ABSTRACT Several rare and common monosaccharides were screened for toxic effects on the Formosan subterranean termite, Coptotermes formosanus Shiraki, with the aim of identifying environmentally friendly termiticides. myo-Inositol and phytic acid, which are nontoxic to mammals, were identified as potential termite control compounds. Feeding bioassays with termite workers, where both compounds were supplied on filter paper in concentrations from 160.2 to $1,281.7 \mu \mathrm{g} / \mathrm{mm}^{3}$, showed concentration-dependent toxicity within $2 \mathrm{wk}$. Interestingly myo-inositol was nontoxic when administered to termites in agar $(40 \mathrm{mg} / \mathrm{ml})$ in the absence of a cellulosic food source, an unexplained phenomenon. In addition, decreased populations of termite hindgut protozoa were observed upon feeding on myo-inositol but not phytate-spiked filter paper. Radiotracer feeding studies using myoinositol- $\left[2-{ }^{3} \mathrm{H}\right]$ with worker termites showed no metabolism after ingestion over a 2 - $\mathrm{d}$ feeding period, ruling out metabolites responsible for the selective toxicity.
\end{abstract}

KEY WORDS Coptotermes formosanus, carbohydrate, sugar, termite, myo-inositol

Of the 28 species in the genus, the Formosan subterranean termite, Coptotermes formosanus Shiraki, is the most destructive and economically important worldwide (Hardy 1988, Henderson 2001, Woodson et al. 2001, Messenger et al. 2002, Su 2003). C. formosanus infestations damage wooden structures of $>50$ species of living plants (Grace et al. 1996, Osbrink et al. 1999, Messenger et al. 2000, Lax and Osbrink 2003), and damage noncellulosic materials such as insulation on buried electrical and telephone wires (Henderson and Dunaway 1999). The first general survey of an exotic C. formosanus infested region in the continental United States was conducted in Louisiana in 1966 (Spink 1967), and the U.S. populations are growing rapidly (Woodson et al. 2001, Lax and Osbrink 2003). A New Orleans, LA, study found termite alates increased by a factor of 14 over a 7 -yr period (Henderson 1996).

C. formosanus digest their wood diets using exogenous endo- $\beta$-1,4-glucanase (cellulase) and $\beta$-glucosidase (cellobiase) enzymes secreted into phagocytotic lumens by symbiotic hindgut protozoa, which are cru-

${ }^{1}$ Department of Biological Sciences, Division of Biochemistry and Molecular Biology, Louisiana State University and A\&M College, Baton Rouge, LA 70803.

${ }^{2}$ Department of Entomology, Louisiana State University Agricultural Center, Baton Rouge, LA 70803.

${ }^{3}$ Department of Experimental Statistics, Louisiana State University and A\&M College, Baton Rouge, LA 70803.

${ }^{4}$ Department of Biology, Xavier University, New Orleans, LA 70125 .

${ }^{5}$ Department of Chemistry, Louisiana State University and A\&M College, Baton Rouge, LA 70803.

${ }^{6}$ Corresponding author, e-mail: rogerlaine@gmail.com. cial in cellulose and lignin metabolism (Yoshimura et al. 1993a,b; Itakura et al. 1997; Watanabe et al. 2002). They also have endogenous endo- $\beta-1,4$-glucanase and $\beta$-glucosidase enzymes expressed in the salivary glands and midgut (Itakura et al. 1997, Nakashima et al. 2002, Zhu et al. 2005). Pseudotrichonympha grassii Koidzumi, Holomastigotoides hartmanni Koidzumi, and Spirotrichonympha leidyi Koidzumi comprise the obligatory C. formosanus hindgut protozoan population (Yoshimura 1995), which themselves have obligatory intracellular bacterial symbionts (Noda et al. $2005,2007)$. Coexisting with these organisms are numerous species of bacteria involved in methanogenesis, acetogenesis, nitrogen fixation, sulfate reduction, and oxygen scavenging (Mertins et al. 1973, Leadbetter and Breznak 1996, Schmitt and Brune 1999, Tholen and Brune 1999, Boga and Brune 2003, Adams and Boopathy 2005) that combine to form a complex and remarkable ancient microecosystem.

Our interest in investigating carbohydrates as termiticides was originally sparked by reports that $D$ tagatose, a rare sugar, was toxic to fly maggots, and was commercialized as Flycracker by Biospherics Inc. (Rockville, MD; Levin and Zehner 1992, Spherix 2002), and is now marketed as an artificial low-calorie sweetener. We screened a number of rare sugars including $D$-tagatose and 2-deoxy- $D$-galactose. While $D$-tagatose had no effect on termites in toxicity screening experiments, 2-deoxy-D-galactose was found to be a potent termiticide, causing significant termite mortality and decreasing hindgut protozoan populations (Veillon et al. 2010). Among the library of sugars tested, myo-inositol (Figs. 4, 6, 8, and 13) and 


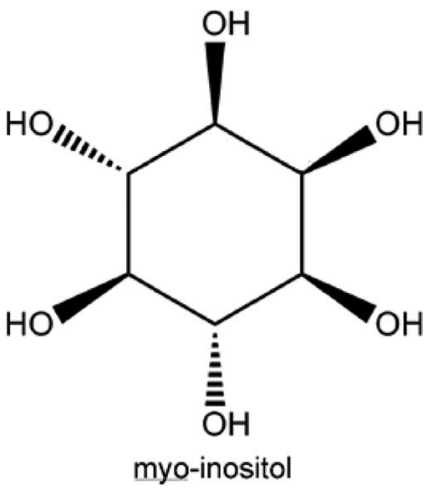

Fig. 1. Chemical structure of myo-inositol.

phytate (Fig. 6) were initially used as controls and were unexpectedly toxic.

Of the nine isomeric forms of cyclohexanehexol, myo-inositol is the isomer most common in biology, although at least five others are found (chiro-, epi-, muco-, neo-, and scyllo-inositols). Unfortunately, for this study, the latter stereoisomers were not available in sufficient quantities to test. myo-Inositol, sold as a dietary supplement in the United States, is biosynthesized de novo from glucose-6-phosphate in a two-step enzymatic process. First, a myo-inositol-3-phosphate synthase-catalyzed $\mathrm{NAD}^{+}$-dependent reaction cyclizes glucose-6-phosphate to D-myo-inositol-3-phosphate (Donahue and Henry 1981; Chen et al. 2000; Loewus and Murthy 2000; Majumder et al. 2003; Daiyasu et al. 2005; Stieglitz et al. 2005), and second, inositol monophosphatase catalyzes dephosphorylation (Stieglitz et al. 2007).

Of the many phosphorylated myo-inositol derivatives, phytate, also known as phytic acid and myo-inositol-1,2,3,4,5,6-hexakisphosphate, is the most abundant. It is accumulated in plant organs and tissues including tubers, turions, roots, and pollen, and is the principal form of phosphorus storage in seeds (Cosgrove 1980, Raboy 1997). The clearest function is for storing and retrieving phosphorous, chelated calcium, other metals, and myo-inositol throughout development and germination. Phytate is ubiquitous in eukaryotes and

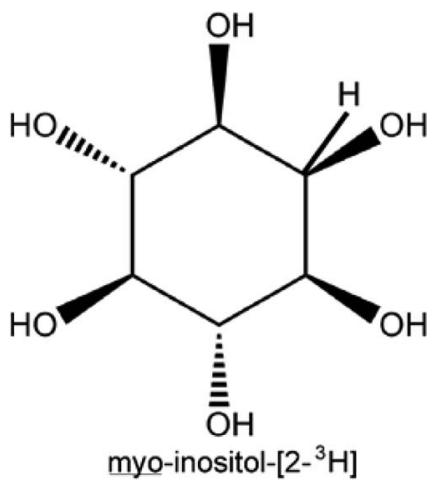

Fig. 2. Chemical structure of myo-inositol- $\left[2-{ }^{3} \mathrm{H}\right]$.

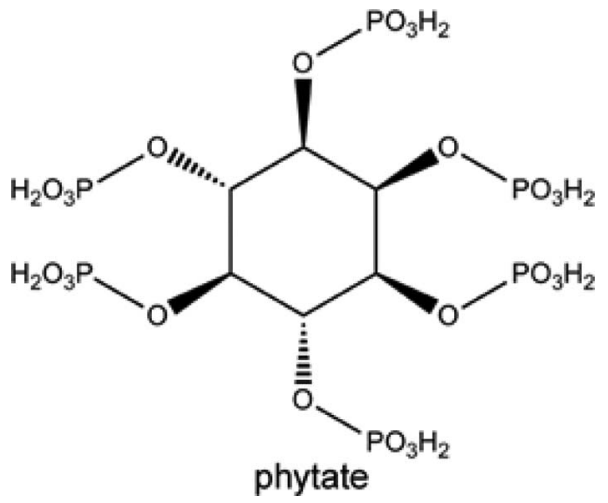

Fig. 3. Chemical structure of phytate.

usually the most plentiful inositol derivative in cells (Sasakawa et al. 1995), where it and other phosphorylated myo-inositol derivatives are involved in numerous functions outside nutrient storage.

myo-Inositol and phytate exhibited concentrationdependent toxicity on C. formosanus. Inositol also had toxic effects on C. formosanus hindgut symbionts.
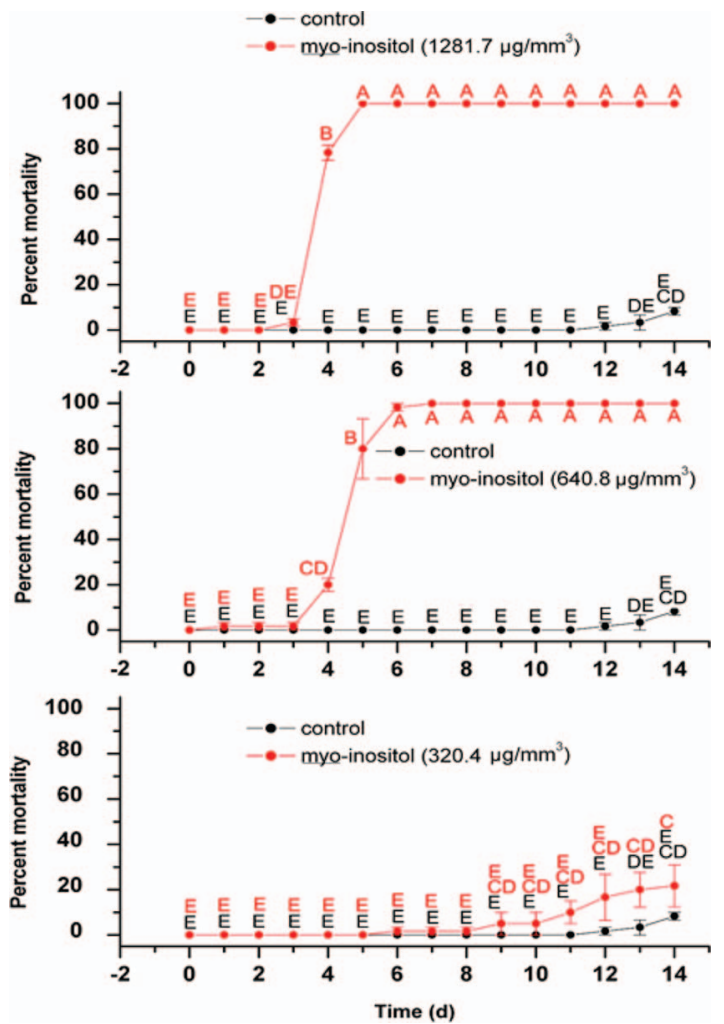

Fig. 4. Means ( $\pm \mathrm{SE})$ of C. formosanus percent mortality following treatment of food source filter paper with myo-inositol in no-choice assays with 20 workers $(n=3)$. Collection group $\mathrm{C}$ was used and the data were recorded daily for $14 \mathrm{~d}$. Means followed by the same letter are not significantly different $(P>$ $0.05)$. The $F$ value for percent mortality is 212.68 . $P$ and $d f$ values are $<0.0001$ and 74,150 , respectively. (Online figure in color.) 


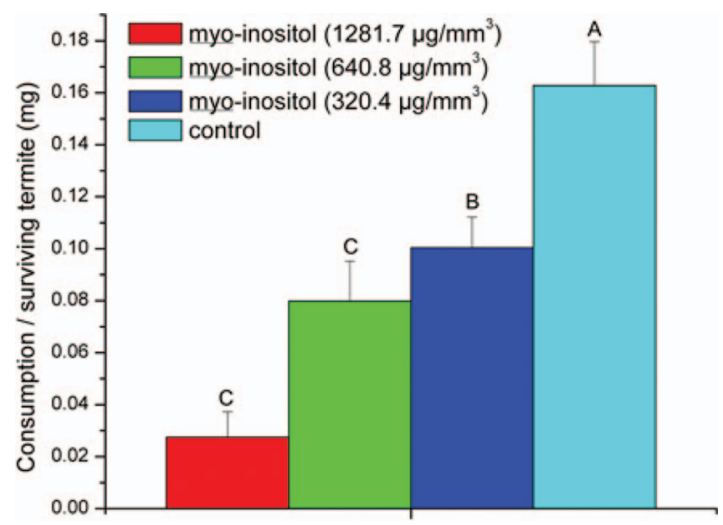

Fig. 5. Means $( \pm \mathrm{SE})$ of C. formosanus filter paper consumption per surviving termite over $14 \mathrm{~d}$. Food source filter paper was treated with myo-inositol before incubation. Collection group C survival data were recorded daily for $2 \mathrm{wk}$. Consumption data were recorded at the end of the 2-wk assay. Groups with statistically similar total consumption values bear the same letter $(P>0.05)$. The total consumption $F$ and $P$ values are 45.99 and 0.0001 , respectively. The $\mathrm{df}$ values are 3 and 8 . (Online figure in color.)

\section{Materials and Methods}

Termite Collection and Colony Maintenance. Worker C. formosanus were collected from Brechtel Park, New Orleans, LA, according to methods described by Smith et al. (2004). Open-mesh plastic containers filled with a lattice of southern yellow pine or spruce-pine-fir sapwood were buried near a $C$. formosanus-infested tree and recovered after 3-9 wk. Termite-containing crates were held in 250-liter plastic garbage cans kept at room temperature $\left(26-28^{\circ} \mathrm{C}\right)$ and $70-80 \%$ relative humidity with the original food source. Collections were as follows: 1 March 2008 (group A, myo-inositol radiotracer study); 9 May 2008 (group B, myo-inositol and D-glucose artificial agar diet-termite assay); 29 May 2008 (group C, myo-inositol $1,281.7,640.8$, and $320.4 \mu \mathrm{g} / \mathrm{mm}^{3}$ dose-mortality assay, and myo-inositol and phytate 1,281.7, 640.8, and $320.4 \mu \mathrm{g} / \mathrm{mm}^{3}$ dose-mortality assay); 20 March 2009 (group D, myo-inositol, 2-deoxy-D-galactose, $D$-glucose and $D$-galactose glucose artificial agar diet-termite assay); 29 May 2009 (group E, myo-inositol 1,281.7, 640.8, 320.4 and $160.2 \mu \mathrm{g} / \mathrm{mm}^{3}$ dose-mortality assay); and 11 May 2010 (group F, both myo-inositol and phytate protozoa quantitation). Termites were extracted on moistened filter paper after tapping infested wood sticks into clean plastic containers.

Chemicals. Neutral red dye, myo-inositol, phytate, myo-inositol-[2- ${ }^{3} \mathrm{H}$ ], 2-deoxy- $D$-galactose, and $D$-sucrose were obtained from Sigma-Aldrich (St. Louis, MO). $D$-galactose and $D$-glucose were obtained from Matheson Coleman and Bell (Cincinnati, $\mathrm{OH}$ ) and Fisher (Fair Lawn, NJ), respectively. Structures of myo-inositol, myo-inositol- $\left[2-{ }^{3} \mathrm{H}\right]$, and phytate are presented in Figs. 1-3, respectively.

Dose-Response Feeding Assays. Test compounds were applied to 42.5 -mm filter papers, in 60 - by $15-\mathrm{mm}$

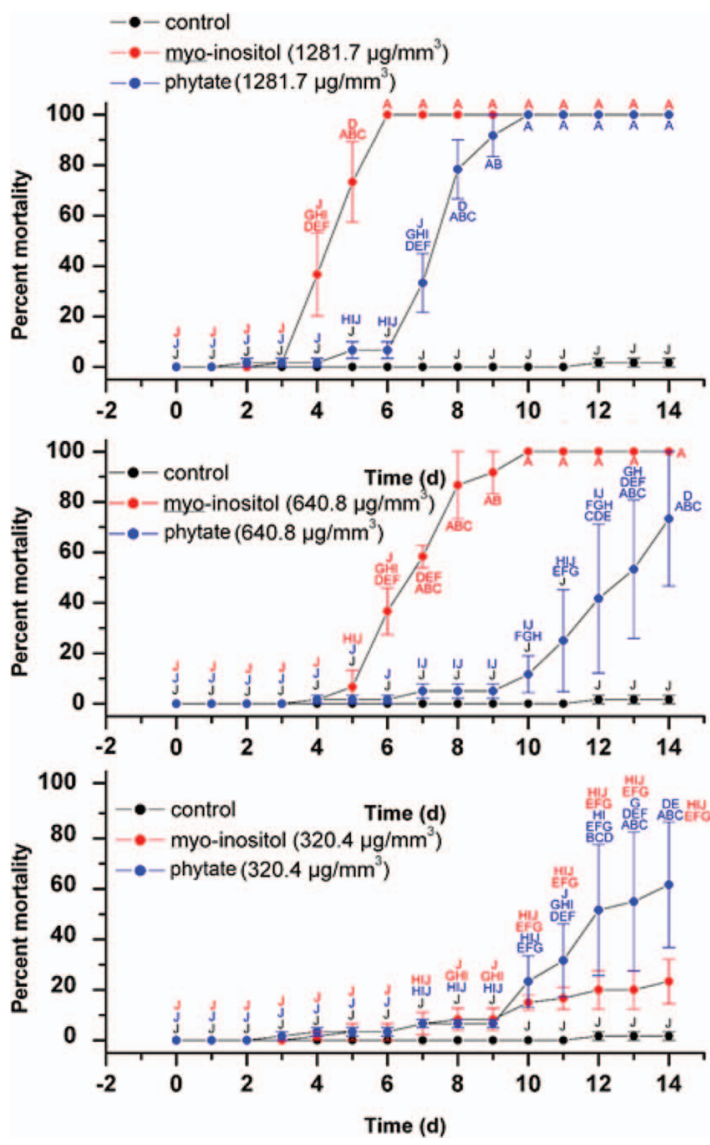

Fig. 6. Means ( $\pm \mathrm{SE}$ ) of C. formosanus percent mortality following treatment of food source filter paper with myoinositol or phytate in no-choice assays with 20 workers $(n=$ 3 ). Collection group $\mathrm{C}$ was used and the data were recorded daily for $14 \mathrm{~d}$. Means followed by the same letter are not significantly different $(P>0.05)$. The $F$ value for percent mortality is 25.76. $P$ and $\mathrm{df}$ values are $<0.0001$ and 119,240 , respectively. (Online figure in color.)

plastic petri dishes. One milligram of carbohydrate per $10 \mu \mathrm{l}$ of distilled water $\left(\mathrm{dH}_{2} \mathrm{O}\right)$ was the stock solution, using $2.5 \mathrm{mg}\left(160.2 \mu \mathrm{g} / \mathrm{mm}^{3}\right.$ of filter paper $), 5 \mathrm{mg}$ $\left(320.4 \mu \mathrm{g} / \mathrm{mm}^{3}\right), 10 \mathrm{mg}\left(640.8 \mu \mathrm{g} / \mathrm{mm}^{3}\right)$, and $20 \mathrm{mg}$ $\left(1,281.7 \mu \mathrm{g} / \mathrm{mm}^{3}\right)$ of myo-inositol. Phytate was tested with the three higher concentrations. $\mathrm{dH}_{2} 0$ was added to bring the volume to $200 \mu \mathrm{l}$ and all control filter papers received $200 \mu \mathrm{l}$ of $\mathrm{dH}_{2} \mathrm{O}$. To prevent desiccation, $100 \mu \mathrm{l}$ of $\mathrm{dH}_{2} \mathrm{O}$ was applied to filter papers throughout the trials pro re nata, approximately every third day. Twenty worker termites were acclimatized in the dark in a Parafilm-sealed petri dish at room temperature for $2 \mathrm{wk}$. Termite mortality was recorded daily for $14 \mathrm{~d}$ in triplicate experiments. A one-way analysis of variance (ANOVA), performed using SAS / STAT software (version 9.1), followed by Tukey's studentized range test was used to evaluate statistical differences among groups (SAS Institute 2002, Cary, NC). All mortality data were judged at $\alpha=0.05$. 


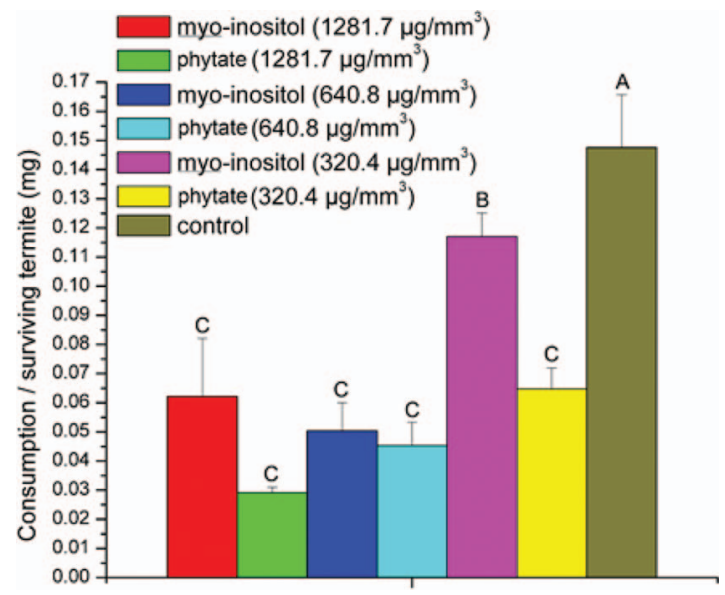

Fig. 7. Means $( \pm \mathrm{SE})$ of C. formosanus filter paper consumption per surviving termite over $14 \mathrm{~d}$. Food source filter paper was treated with myo-inositol or phytate before incubation. Collection group $\mathrm{C}$ survival data were recorded daily for $2 \mathrm{wk}$. Consumption data were recorded at the end of the 2-wk assay. Groups with statistically similar total consumption values bear the same letter $(P>0.05)$. The total consumption $F$ and $P$ values are 38.15 and 0.0001 , respectively. The $\mathrm{df}$ values are 6 and 14. (Online figure in color.)
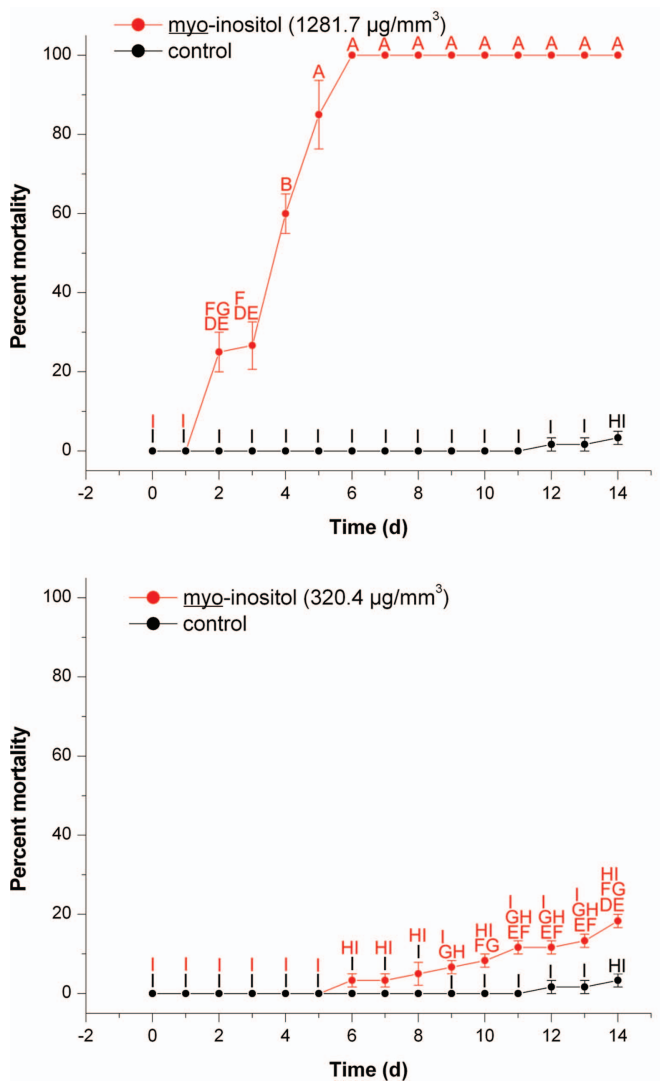

Table 1. Parameters used in evaluating CLL modeling of timeconcentration-mortality for $C$. formosanus workers subjected to myo-inositol and phytate

\begin{tabular}{|c|c|c|c|c|c|}
\hline Treatment & $\mathrm{df}$ & $\begin{array}{c}\text { Scaled } \\
\text { deviance }\end{array}$ & $\begin{array}{c}\text { Mean } \\
\text { deviance }\end{array}$ & Slope $(\beta)$ & SE of B \\
\hline myo-Inositol & 533 & 1358.4 & 2.59 & 0.9297 & 0.0842 \\
\hline Phytate & 178 & 355.16 & 2 & 1.46 & 0.3413 \\
\hline
\end{tabular}

Termites from collection group $\mathrm{C}$ were used in both the myo-inositol 1,281.7, 640.8, and $320.4 \mu \mathrm{g} / \mathrm{mm}^{3}$ dose-mortality assay and the myo-inositol and phytate $1,281.7,640.8$, and $320.4 \mu \mathrm{g} / \mathrm{mm}^{3}$ dose-mortality assay, and termites from collection group $\mathrm{E}$ were used in the myo-inositol 1,281.7, 640.8, 320.4, and $160.2 \mu \mathrm{g} / \mathrm{mm}^{3}$ dose-mortality assay.

In paper consumption experiments, filter papers were weighed before sugar application. After $14 \mathrm{~d}$, termites were removed from the dishes and filter paper from each replicate was cleaned, washed of residual carbohydrate, and dried at $100^{\circ} \mathrm{C}$ for $24 \mathrm{~h}$. After drying and acclimated for $24 \mathrm{~h}$, filter papers were reweighed. Statistical differences among groups were evaluated using ANOVA followed by Tukey's Studen-
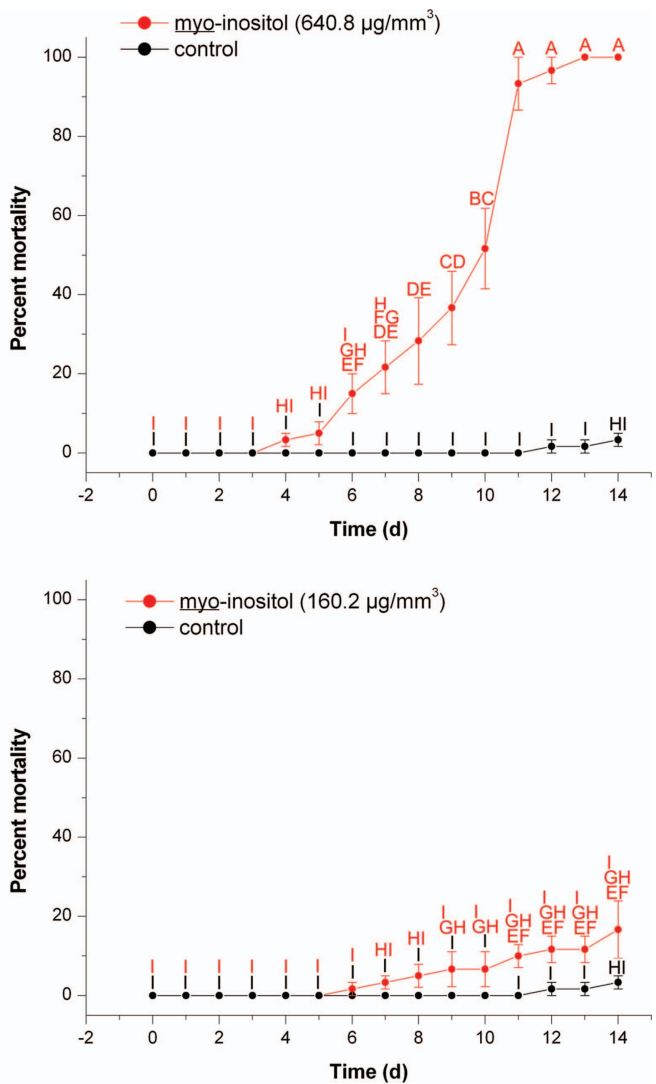

Fig. 8. Means $( \pm \mathrm{SE})$ of $C$. formosanus percent mortality following treatment of food source filter paper with myo-inositol in no-choice assays with 20 workers $(n=3)$. Collection group $\mathrm{E}$ was used and the data were recorded daily for $14 \mathrm{~d}$. Means followed by the same letter are not significantly different $(P>0.05)$. The $F$ value for percent mortality is $134.81 . P$ and $\mathrm{df}$ values are $<0.0001$ and 74,150 , respectively. (Online figure in color.) 


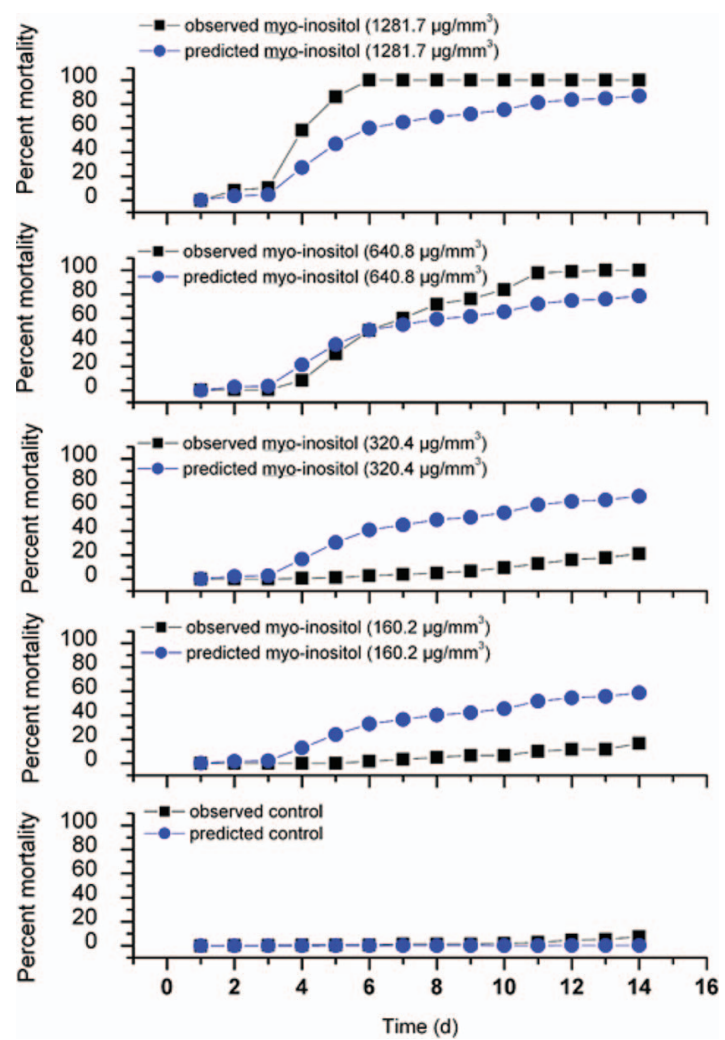

Fig. 9. Relationship between observed and CLL model predicted percentage mortality, myo-inositol concentration, and time for C. formosanus workers. (Online figure in color.)

tized range test. All consumption data were judged at $\alpha=0.05$.

Complementary Log-Log (CLL) Modeling. A serial time-concentration-mortality design was implemented, and conditional mortality probability was estimated using the CLL model described by Robertson and Preisler (1992). SAS PROC GENMOD (SAS Institute 2002) was used to obtain maximum likelihood estimates of the conditional response parameters, which were in turn used to estimate cumulative mortality probabilities (Robertson and Preisler 1992). A small positive amount was added to all concentration levels to include controls (Robertson and Preisler 1992). $\mathrm{LC}_{50}$ and $\mathrm{LC}_{90}$ values with confidence limits were estimated for myo-inositol and phytate using the formulae given by Robertson and Preisler (1992), and $\mathrm{LT}_{50}$ values were estimated by linear interpolation (Nowierski et al. 1996, Feng et al. 1998). In addition, pooled myo-inositol data were subjected to ANOVA followed by Tukey's Studentized range test. All data were judged at $\alpha=0.05$.

Protozoan Counting. The effect of myo-inositol and phytate on C. formosanus hindgut protozoan populations was examined as follows: Twenty milligrams of myo-inositol or phytate were dissolved in $200 \mu \mathrm{l}$ of $\mathrm{dH}_{2} \mathrm{O}$ and applied to filter paper, in a 60 - by $15-\mathrm{mm}$ plastic petri dish $\left(1,281.7 \mu \mathrm{g} / \mathrm{mm}^{3}\right)$. Control filter pa-
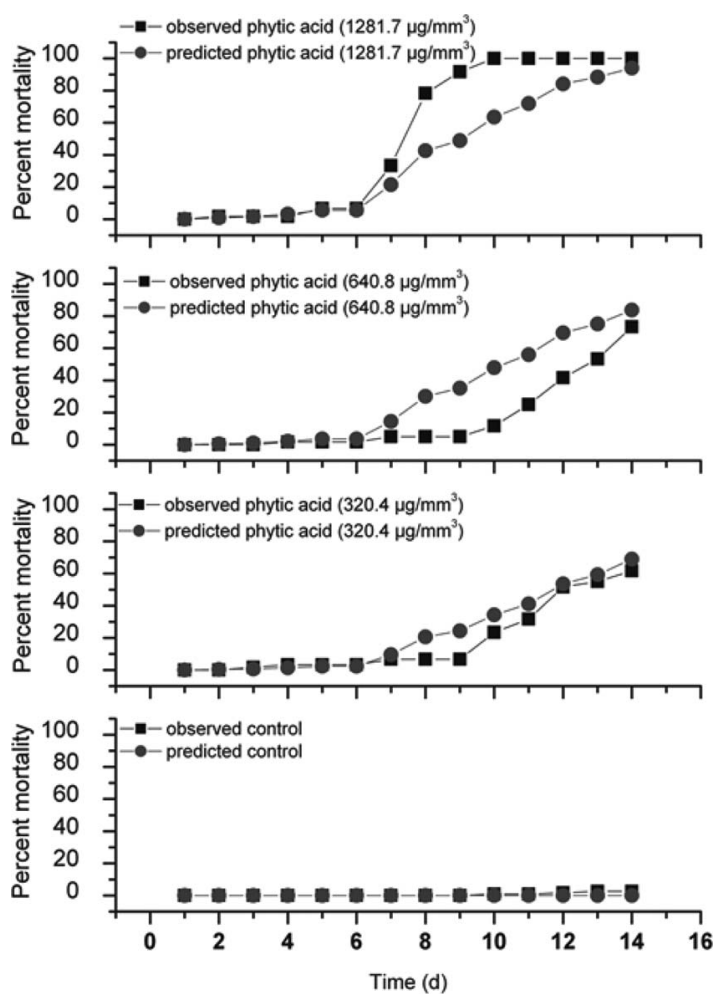

Fig. 10. Relationship between observed and CLL model predicted percentage mortality, phytate concentration, and time for C. formosanus workers.

per received $200 \mu \mathrm{l}$ of $\mathrm{dH}_{2} \mathrm{O}$. Seventy-five worker termites were placed in each dish and collection group $\mathrm{F}$ was used in both myo-inositol assays and the phytate assay. P. grassii, H. hartmanni, and S. leidyi Koidzumi were counted daily for $2 \mathrm{wk}$, as described by Mannesmann (1972) and modified by Maistrello et al. (2002). Hindguts were removed from three workers and gently macerated in $40 \mu \mathrm{l}$ of saline solution containing neutral red dye $(0.5 \mathrm{ml}$ of $1 \%$ aqueous neutral red solution dissolved in $10 \mathrm{ml}$ of saline solution). The number of each protozoan species was determined with a hemocytometer (Bright-line Improved Neubauer, Hausser Scientific, Horsham, PA) under a light microscope. The population of each protozoan species per hindgut $\left(\mathrm{X}_{\mathrm{F}}\right)$ was calculated as: $\mathrm{X}_{\mathrm{F}-}=(G \times n) /(V$ $\times 3$ ), where $G=$ volume $(\mu \mathrm{l})$ of solution in which hindguts were dissected; $n=$ mean of two counts within hemocytometer; and $V=$ volume $(\mu \mathrm{l})$ of area counted. Mean $( \pm \mathrm{SE}) \mathrm{X}_{\mathrm{F}}$ values calculated from two replicates were used for graphical comparison of data. Protozoan population data were subjected to ANOVA followed by a Tukey's Studentized range test, all data were judged at $\alpha=0.05$. A square-root transformation was applied for data analysis; however, untransformed means are reported.

myo-Inositol Administered in the Absence of Cellulose Feeding Bioassay. Artificial diets were prepared as described by Tanaka et al. (2006). Briefly, 400 $\mathrm{mg} / 10 \mathrm{ml}$ of selected sugars and $150 \mathrm{mg} / 10 \mathrm{ml}$ of agar 
Table 2. Estimates of $\mathrm{LC}_{50}$ and $\mathrm{LC}_{90}$ in $\mu \mathrm{g} / \mathrm{mm} 3$ with $95 \%$ confidence intervals at different periods for $C$. formosanus workers

\begin{tabular}{|c|c|c|c|c|}
\hline Treatment & Time $(d)$ & $\mathrm{LC}_{50}(95 \%$ limits $)$ & Time $(\mathrm{d})$ & $\mathrm{LC}_{90}(95 \%$ limits $)$ \\
\hline \multirow[t]{14}{*}{ myo-Inositol } & 1 & $1892807080^{a} \pm 2033.5$ & 1 & $37061322741^{a} \pm 2880$ \\
\hline & 2 & $1627859.1^{a} \pm 93.5$ & 2 & $31873618.1^{a} \pm 114$ \\
\hline & 3 & $954130.7^{a} \pm 88.15$ & 3 & $18681960.5^{a} \pm 106.35$ \\
\hline & 4 & $8778.3^{a} \pm 67.3$ & 4 & $171879.4^{a} \pm 73.6$ \\
\hline & 5 & $1594.4^{a} \pm 65.2$ & 5 & $31218.1^{a} \pm 69$ \\
\hline & 6 & $629.9 \pm 64.75$ & 6 & $12334.4^{a} \pm 67.3$ \\
\hline & 7 & $457.3 \pm 64.7$ & 7 & $8954.1^{a} \pm 66.85$ \\
\hline & 8 & $335.8 \pm 64.65$ & 8 & $6574.5^{a} \pm 66.45$ \\
\hline & 9 & $288.4 \pm 64.65$ & 9 & $5647.3^{a} \pm 66.25$ \\
\hline & 10 & $221.8 \pm 64.7$ & 10 & $4343.1^{a} \pm 66$ \\
\hline & 11 & $142 \pm 64.75$ & 11 & $2781.3^{a} \pm 65.55$ \\
\hline & 12 & $116.9 \pm 64.85$ & 12 & $2288^{a} \pm 65.4$ \\
\hline & 13 & $107.4 \pm 64.85$ & 13 & $2103.9^{a} \pm 65.35$ \\
\hline & 14 & $88 \pm 64.95$ & 14 & $1723.3^{a} \pm 65.2$ \\
\hline \multirow[t]{14}{*}{ Phytate } & 1 & CI could not be calculated & 1 & CI could not be calculated \\
\hline & 2 & $1450894.6^{a} \pm 735.75$ & 2 & $9691371^{a} \pm 1587.2$ \\
\hline & 3 & $482701.6^{a} \pm 296.25$ & 3 & $3224245.1^{a} \pm 578.45$ \\
\hline & 4 & $160184^{a} \pm 165.6$ & 4 & $1069962.4^{a} \pm 292.55$ \\
\hline & 5 & $65161.5^{a} \pm 119.55$ & 5 & $435251.9^{a} \pm 194.75$ \\
\hline & 6 & $65161.5^{a} \pm 119.55$ & 6 & $435251.9^{a} \pm 194.75$ \\
\hline & 7 & $6790.2^{a} \pm 74.95$ & 7 & $45356^{a} \pm 99.7$ \\
\hline & 8 & $1817^{a} \pm 66.9$ & 8 & $12136.6^{a} \pm 79.6$ \\
\hline & 9 & $1346.7^{a} \pm 66.05$ & 9 & $8995.7^{a} \pm 76.75$ \\
\hline & 10 & $705.8 \pm 65.05$ & 10 & $4714.6^{a} \pm 71.85$ \\
\hline & 11 & $490.4 \pm 64.95$ & 11 & $3275.4^{a} \pm 69.7$ \\
\hline & 12 & $272.3 \pm 65.5$ & 12 & $1818.9^{a} \pm 67$ \\
\hline & 13 & $212.5 \pm 66.05$ & 13 & $1419.7^{a} \pm 66.15$ \\
\hline & 14 & $139.6 \pm 67.45$ & 14 & $932.4 \pm 65.2$ \\
\hline
\end{tabular}

${ }^{a}$ Estimate is extrapolated as the highest concentration used was $1,281.7 \mu \mathrm{g} / \mathrm{mm}^{3}$.

were dissolved in $\mathrm{dH}_{2} \mathrm{O}, \mathrm{pH}$ 6.8. Sugar and agar solutions were autoclaved separately. Agar-sugar solutions were poured in 60- by $15-\mathrm{mm}$ polystyrene petri dishes $5 \mathrm{~mm}$ in depth, allowed to solidify, and then divided into quadrants. myo-Inositol, $D$-glucose, 2 -deoxy- $D$-galactose, and $D$-galactose were all examined as carbon sources in addition to one group that received unsupplemented agar. In triplicate experiments, 20 worker termites from collection group $\mathrm{B}$, for the myoinositol and $D$-glucose (40 $\mathrm{mg} / \mathrm{ml}$ agar) assay, or collection group $\mathrm{D}$, for the myo-inositol, $D$-glucose, $D$ galactose, 2-deoxy- $D$-galactose (40 $\mathrm{mg} / \mathrm{ml}$ agar), and agar-alone assay, were placed in $60-$ by $15-\mathrm{mm}$ poly-

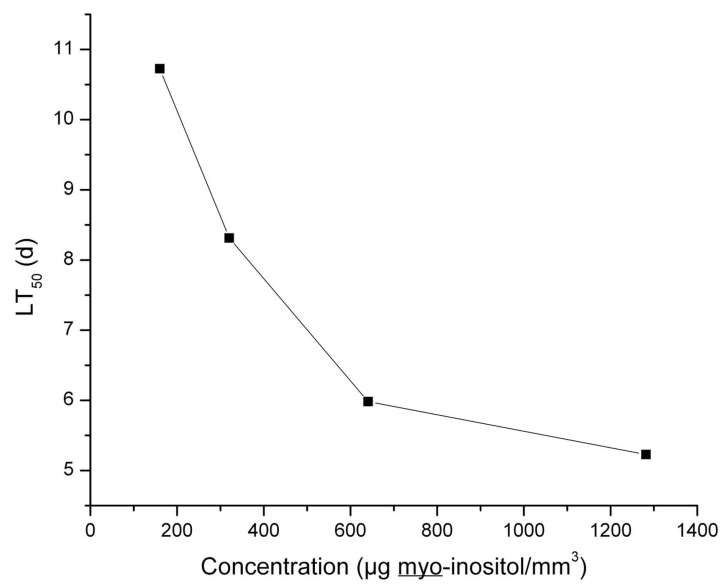

Fig. 11. Concentration-dependent $\mathrm{LT}_{50}$ estimates for myo-inositol on C. formosanus workers. styrene petri dishes and provided with an agar-sugar quadrant to serve as a food and water source. After $14 \mathrm{~d}$, termites were removed from the dishes. Mortality data were subjected to ANOVA followed by Tukey's Studentized range test. All mortality data were judged at $\alpha=0.05$.

myo-Inositol Radiotracer Study. Food source filter paper was treated with $25 \mu \mathrm{l}$ of unlabeled $555 \mathrm{mM}$ myo-inositol solution and $10 \mu \mathrm{l}$ of a $500 \mathrm{nM}$ myoinositol- $\left[2-{ }^{3} \mathrm{H}\right]$ solution, specific activity $10-20 \mathrm{Ci} /$ $\mathrm{mM}$. Twenty worker termites, from collection group A, were fed treated paper for $2 \mathrm{~d}$ and frozen. Frozen termites were homogenized and a Bligh and Dyer

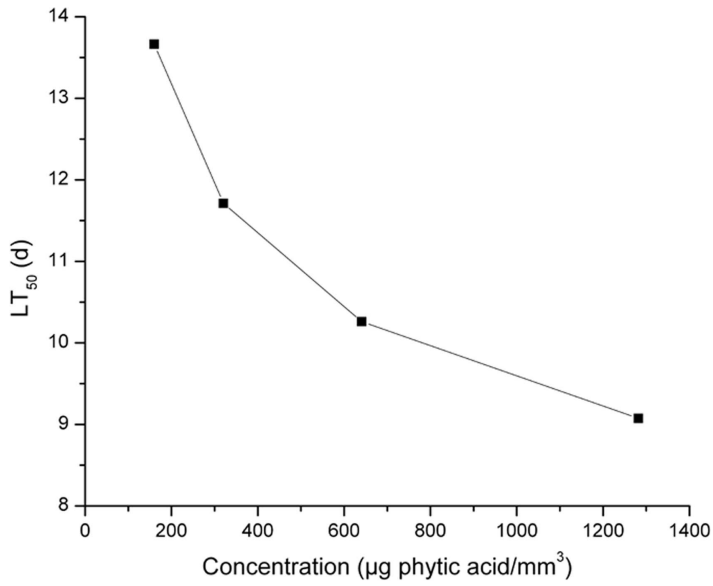

Fig. 12. Concentration-dependent $\mathrm{LT}_{50}$ estimates for phytate on C. formosanus workers. 

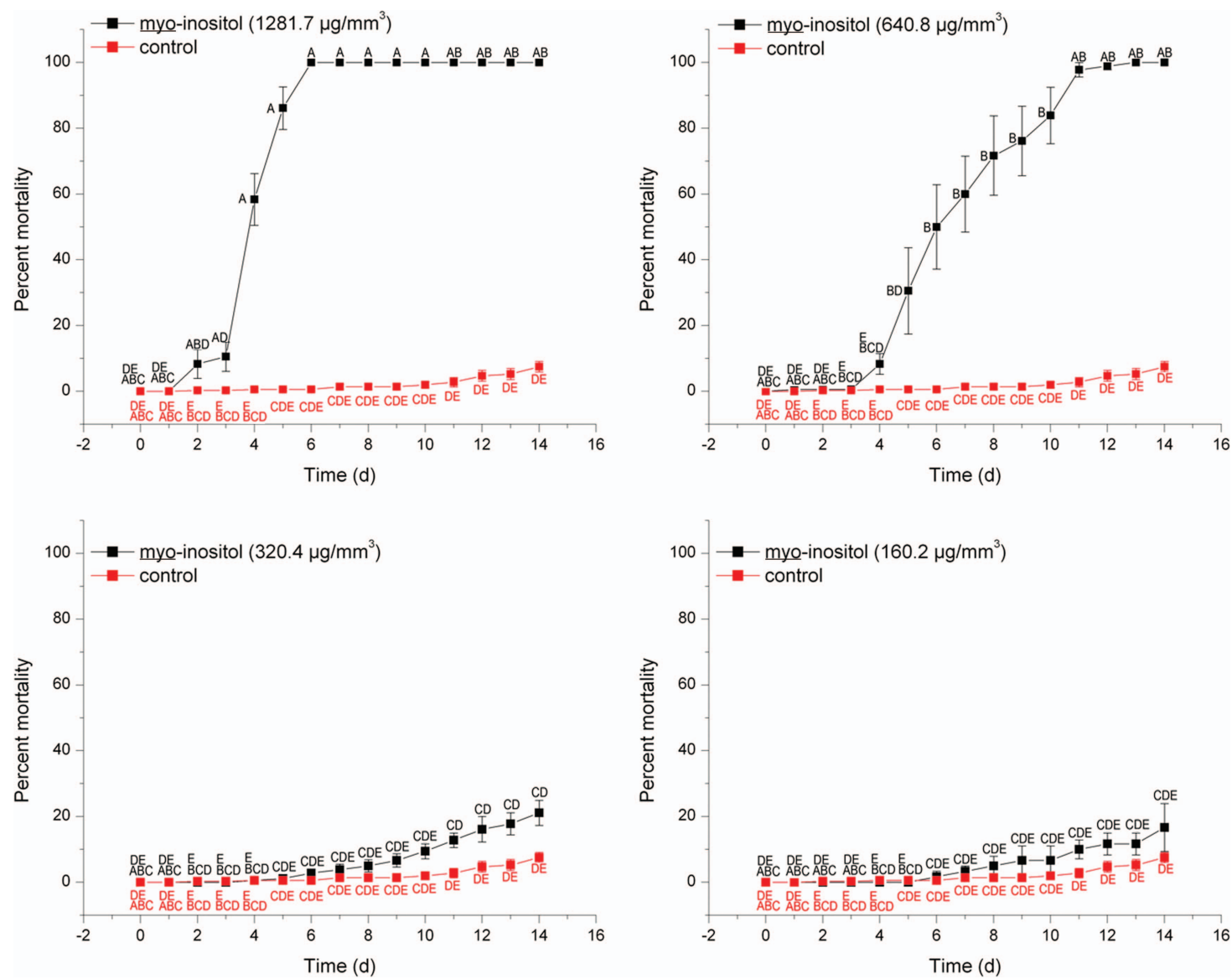

Fig. 13. Means $( \pm \mathrm{SE})$ of pooled C. formosanus percent mortality following treatment of food source filter paper with myo-inositol in no-choice assays with 20 workers. Collection groups $\mathrm{C}$ and $\mathrm{E}$ were used and the data were recorded daily for $14 \mathrm{~d}$. Means followed by the same letter are not significantly different $(P>0.05)$. For controls, 160.2, 320.4, 640.8, and $1,281.7 \mu \mathrm{g} / \mathrm{mm}^{3}$ treatment groups, $n$ values are $18,3,9,9$, and 9 , respectively. The $F$ value for percent mortality is $115.72 . P$ and $\mathrm{df}$ values are $<0.0001$ and 74,645 , respectively. (Online figure in color.)

(Bligh and Dyer 1959) extraction was performed. Aqueous and lipid fractions were concentrated and liquid scintillation counting (LSC) was used to measure radioactivity. The aqueous soluble fraction was fractionated with a silica column $(1 \mathrm{~cm}$ in diameter and $8 \mathrm{~cm}$ in length) using 4:1 acetonitrile: $\mathrm{dH}_{2} \mathrm{O}$ as the mobile phase. Eighty 1-ml fractions were collected and LSC was used to evaluate radioactivity. Radioactive fractions were chromatographed on silica thinlayer plates using 4:1 acetonitrile: $\mathrm{dH}_{2} \mathrm{O}$ as the mobile phase. Chromatograms were visualized with iodine vapor and retardation factor $\left(R_{f}\right)$ values were compared with myo-inositol standards. Fractions were scraped from the plates with a razor and radioactivity was measured using LSC.

\section{Results}

Dose-Response Feeding Assays. myo-Inositol (1,281.7, 640.8, and $320.4 \mu \mathrm{g} / \mathrm{mm}^{3}$ ): Concentration-Dependent Toxicity. Mortality was significant after $3 \mathrm{~d}$ in workers treated with both $1,281.7$ and $640.8 \mu \mathrm{g} / \mathrm{mm}^{3}$ of myo- inositol compared with controls (Fig. 4). The 640.8 $\mu \mathrm{g} / \mathrm{mm}^{3}$ treatment induced $100 \%$ mortality by day 7 and the $1,281.7 \mu \mathrm{g} / \mathrm{mm}^{3}$ treatment by day 5 (Fig. 4). The $320.4 \mu \mathrm{g} / \mathrm{mm}^{3}$ treatment did not show significant mortality during the 14-d assay.

myo-Inositol $\left(1,281.7,640.8\right.$, and $\left.320.4 \mu \mathrm{g} / \mathrm{mm}^{3}\right)$ : Decreased Paper Consumption. All three treatments caused a concentration-dependent decrease in filter paper consumption (Fig. 5). During the 2-wk assay, each control worker consumed, on average, $0.162 \mathrm{mg}$ of filter paper (Fig. 5). Individual workers feeding on filter paper treated with myo-inositol consumed an average of $0.027,0.079$, and $0.1 \mathrm{mg}$ with the 1,281.7, 640.8 , and $320.4 \mu \mathrm{g} / \mathrm{mm}^{3}$ treatments; Fig. 5).

myo-Inositol and Phytate $(1,281.7,640.8$, and 320.4 $\left.\mu \mathrm{g} / \mathrm{mm}^{3}\right)$ : Concentration-Dependent Toxicity. With the $1,281.7 \mu \mathrm{g} / \mathrm{mm}^{3}$ treatment, myo-inositol induced significant mortality after day $4(100 \%$ on day 6$)$, phytate after day 7 (100\% on day 10; Fig. 6). At 640.8 $\mu \mathrm{g} / \mathrm{mm}^{3}$, myo-inositol caused significant mortality after day 6 ( $100 \%$ on day 10$)$, while phytate results were significant after day 12 with $73 \%$ mortality by day 14 

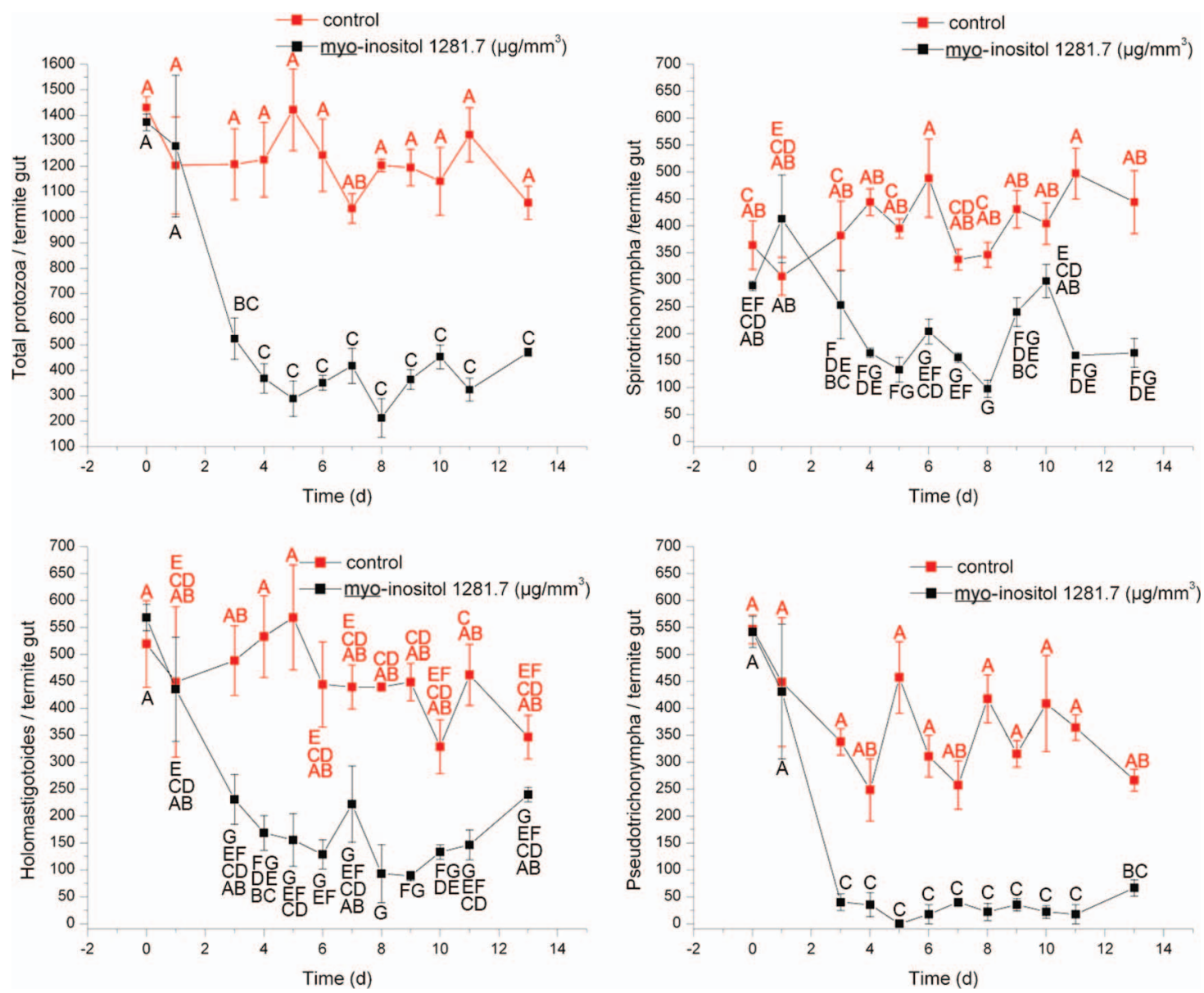

Fig. 14. Means $( \pm \mathrm{SE})$ of C. formosanus hindgut protozoan counts. The hindgut protozoa of workers from collection group F were enumerated for $14 \mathrm{~d}$ while termites were allowed to feed on filter paper treated with $1,281.7 \mu \mathrm{g} / \mathrm{mm}^{3} \mathrm{of} \mathrm{myo-inositol}$. Means followed by the same letter are not significantly different $(P>0.05)$. The $F$ values for total protozoa, Pseudotrichonympha, Holomastigotoides, and Spirotrichonympha are $21.77(P=<0.0001), 23.12(P=<0.0001), 7.83(P=<0.0001)$, and $12.18(P=<0.0001)$, respectively. The $\mathrm{df}$ value is 23,48 for all. (Online figure in color.)

(Fig. 6). At $320.4 \mu \mathrm{g} / \mathrm{mm}^{3}$, myo-inositol did not cause significant mortality, whereas phytate showed significant mortality after day 11 , and $62 \%$ mortality after day 14 (Fig. 6).

myo-Inositol and Phytate (1,281.7, 640.8, and 320.4 $\left.\mu \mathrm{g} / \mathrm{mm}^{3}\right)$ : Decreased Paper Consumption. All three concentrations, for both myo-inositol and phytate, significantly reduced average cellulose consumption per surviving termite when compared with controls (Fig. 7). Consumption on myo-inositol treated filter paper averaged $0.062,0.05$, and $0.116 \mathrm{mg}$ at $1,281.7,640.8$, and $320.4 \mu \mathrm{g} / \mathrm{mm}^{3}$ treatments, respectively (Fig. 7). Phytate was more effective than myo-inositol at $0.029,0.045$, and $0.064 \mathrm{mg}$ consumption, respectively (Fig. 7).

myo-Inositol (1,281.7, 640.8, 320.4, and $160.2 \mu \mathrm{g} /$ $\left.\mathrm{mm}^{3}\right)$ : Concentration-Dependent Toxicity. On day 14, mortality was not significant with 160.2 or $320.4 \mu \mathrm{g} /$ $\mathrm{mm}^{3}$ myo-inositol (Fig. 8), while the $640.8 \mu \mathrm{g} / \mathrm{mm}^{3}$ became significant on day 7 (Fig. 8), and the 1,281.7 $\mu \mathrm{g} / \mathrm{mm}^{3}$ after day 1 with $100 \%$ mortality on day 6 (Fig. 8).

Intercollection Group Variation in Dose-Mortality Assays. The effects of 1,281.7, 640.8, and $320.4 \mu \mathrm{g} /$ $\mathrm{mm}^{3}$ treatments of myo-inositol were examined in three separate mortality bioassays. Collection group $\mathrm{E}$ was used in the myo-inositol 1,281.7, 640.8, 320.4, and $160.2 \mu \mathrm{g} / \mathrm{mm}^{3}$ dose-mortality assay. In the remaining two assays, collection group $\mathrm{C}$ was used. We examined variation between groups collected from the field at different times, and also between groups collected from the same holding container at different times $(\mathrm{C}$ and C'). Results of ANOVA followed by Tukey's Studentized range test (SAS Institute 2002) indicated no intercollection group variation in resistance to myoinositol induced mortality at the $320.4 \mu \mathrm{g} / \mathrm{mm}^{3}$ treatment level. However, at the 640.8 and $1,281.7 \mu \mathrm{g} / \mathrm{mm}^{3}$ treatment levels, some variation was observed. Specifically, at the $640.8 \mu \mathrm{g} / \mathrm{mm}^{3}$ dose, mortality in group $\mathrm{C}$ was significantly different from groups $\mathrm{E}$ and $\mathrm{C}$ ' on 

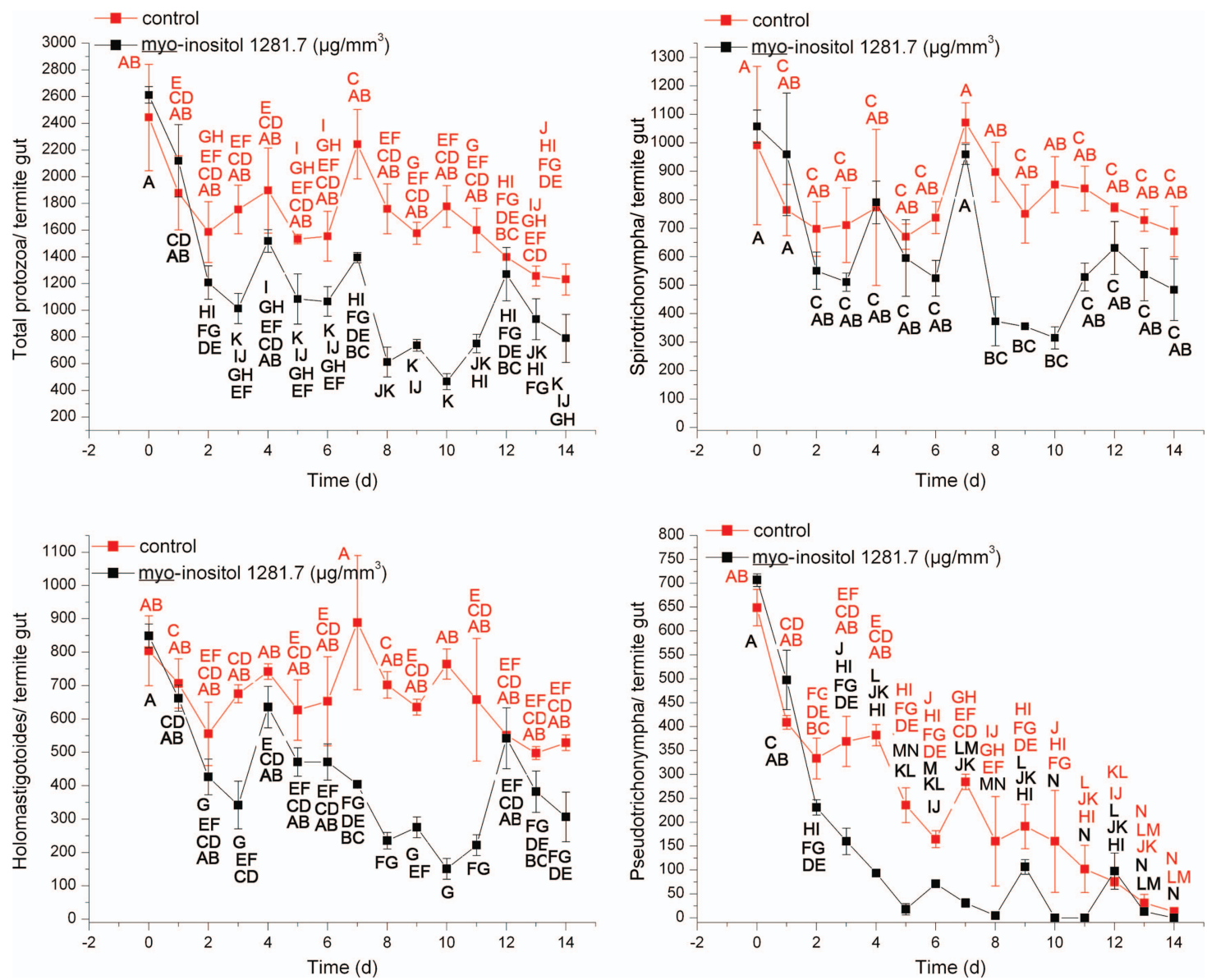

Fig. 15. Means $( \pm \mathrm{SE})$ of $C$. formosanus hindgut protozoan counts. The hindgut protozoa of workers from collection group $\mathrm{F}$ were enumerated daily for $14 \mathrm{~d}$ while termites were allowed to feed on filter paper treated with $1,281.7 \mu \mathrm{g} / \mathrm{mm}^{3} \mathrm{of}$ myo-inositol. Means followed by the same letter are not significantly different $(P>0.05)$. The $F$ values for total protozoa, Pseudotrichonympha, Holomastigotoides, and Spirotrichonympha are $10.72(P=<0.0001), 26.71(P=<0.0001), 7.76(P=$ $<0.0001)$, and $3.69(P=<0.0001)$, respectively. The df value is 29,60 for all. (Online figure in color.)

days 4-6. At the same dose, mortalities in all three groups were different on day 7 , and group $\mathrm{E}$ was different from groups $\mathrm{C}$ and $\mathrm{C}^{\prime}$ on days 8-10. In addition, at $1,281.7 \mu \mathrm{g} / \mathrm{mm}^{3}$, mortality in collection group $\mathrm{E}$ was significantly different than both collection groups $\mathrm{C}$ and $\mathrm{C}^{\prime}$ on days 2 and 3.

CLL Modeling of Mortality Data. The results of time-concentration-mortality CLL modeling of $C$. formosanus are shown in Table 1 . The $\beta$ parameter from the maximum likelihood estimation in the CLL model is the slope value $(\beta)$. The relationship between time, concentration, and mortality using the CLL model for myo-inositol and phytate against $C$. formosanus is presented with the observed mortality for comparison in Figs. 9 and 10, respectively. CLL modeling for both compounds resulted in a trend of accumulated mortality over time increasing with concentration. $\mathrm{LC}_{50}$ and $\mathrm{LC}_{90}$ estimates with $95 \%$ CIs for myo-inositol and phytate against C. formosanus are shown in Table 2 . The highest concentration evaluated for both compounds was $1,281.7 \mu \mathrm{g} / \mathrm{mm}^{3}$ (20 mg per 42 $\mathrm{mm}$ of filter paper), so concentrations exceeding this value are extrapolated. Figures 11 and 12 depict the $\mathbf{L T}_{50}$ estimates for myo-inositol and phytate against C. formosanus. Estimated $\mathrm{LT}_{50}$ values decreased with increasing concentration (Figs. 11 and 12).

When myo-inositol mortality data were pooled and subjected to ANOVA followed by Tukey's Studentized range test (SAS Institute 2002), mortalities were significantly different from controls after days 3 and 5 in the $1,281.7$ and $640.88 \mu \mathrm{g} / \mathrm{mm}^{3}$ treatment groups (Fig. 13), but not in the 320.4 and $160.27 \mu \mathrm{g} / \mathrm{mm}^{3}$ treatment groups (Fig. 13).

Effect on Protozoan Populations. myo-Inositol Bioassay. There was some variation in results of feeding on filter paper treated with $1,281.7 \mu \mathrm{g} / \mathrm{mm}^{3}$ on total protozoan populations, with Test 1 showing significance on day 3 (Fig. 14) for P. grassii (Fig. 14) and reduced populations on days 4,5 , and 8 , and days $4-8$, 11, and 13 for H. hartmanni and S. leidyi (Fig. 14). In Test 2, at $1,281.7 \mu \mathrm{g} / \mathrm{mm}^{3}$, myo-inositol-treated protozoan populations became significant on days 8-11 

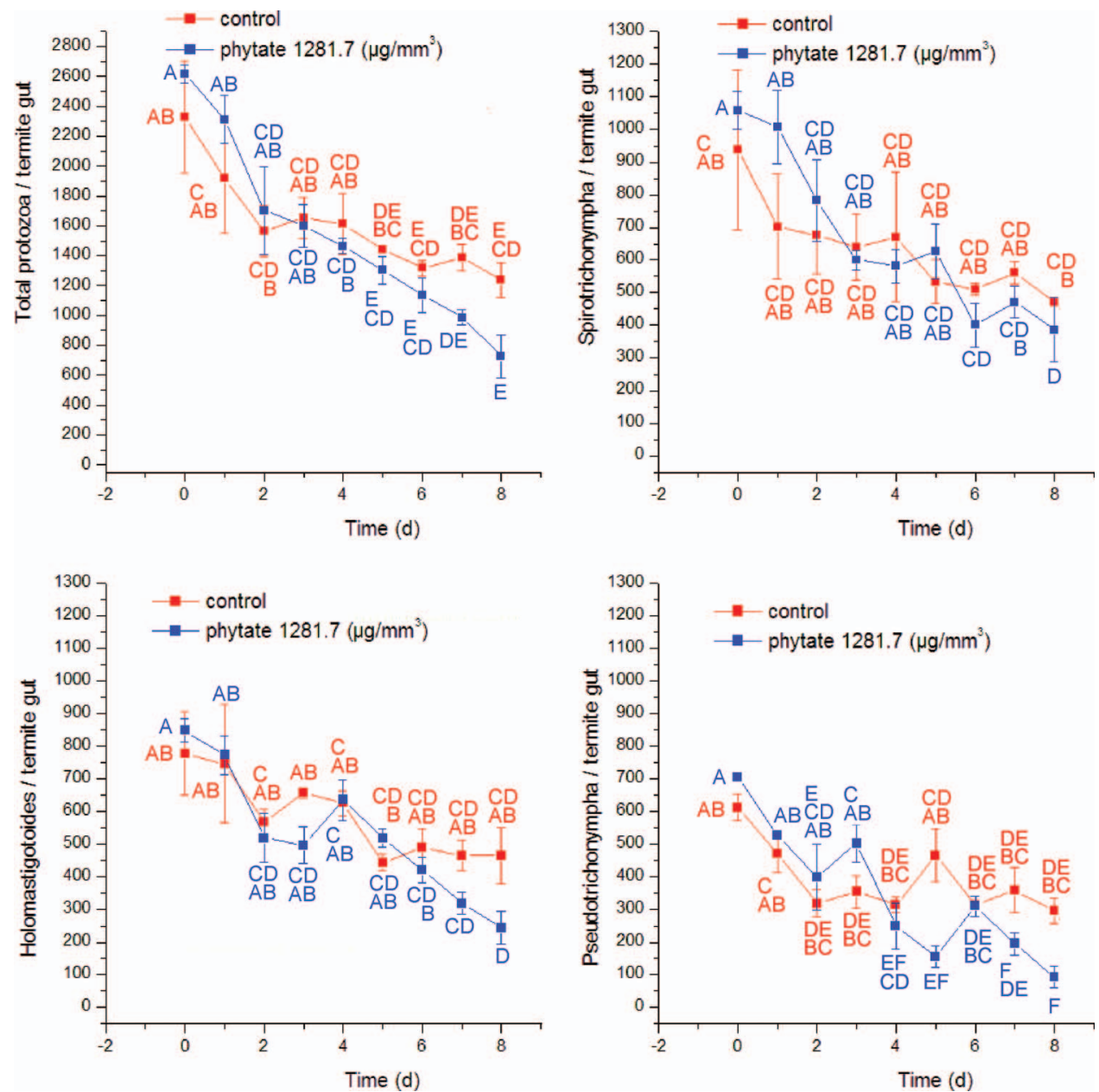

Fig. 16. Means $( \pm \mathrm{SE})$ of C. formosanus hindgut protozoan counts. The hindgut protozoa of workers from collection group F were enumerated daily for $8 \mathrm{~d}$ while termites were allowed to feed on filter paper treated with $1,281.7 \mu \mathrm{g} / \mathrm{mm}^{3}$ of phytate. Means followed by the same letter are not significantly different $(P>0.05)$. The $F$ values for total protozoa, Pseudotrichonympha, Holomastigotoides, and Spirotrichonympha are $7.49(P=<0.0001), 9.02(P=<0.0001), 5.66(P=<0.0001)$, and 3.28 $(P=0.0013)$, respectively. The $\mathrm{df}$ value is 17,36 for all. (Online figure in color.)

(Fig. 15) with $P$. grassii populations being significantly lower than controls on days 4, 5, 7, 8, 10, and 11 (Fig. 15). H. hartmanni populations were also significantly reduced on days $7,8,10$, and 11 .

Phytate Bioassay on Protozoans $\left(1,281.7 \mu \mathrm{g} / \mathrm{mm}^{3}\right)$ : No Significant Impact. A $1,281.7 \mu \mathrm{g} / \mathrm{mm}^{3}$ treatment of phytate did not significantly reduce any of the three protozoan populations (Fig. 16).

Termite Agar Diet Assays. myo-Inositol and D-glucose $(40 \mathrm{mg} / \mathrm{ml}$ agar $)$. Reduced Toxicity. Interestingly, in the absence of cellulose, myo-inositol failed to induce mortality different from that of $D$-glucose controls (Fig. 17).

myo-Inositol, D-glucose, D-galactose, 2-deoxy-D-galactose (40 mg/ml Agar), and Agar Alone. Reduced Toxicity. Figure 18 shows results with agar-alone, $D$-galactose, and 2-deoxy- $D$-galactose groups. myo-Inositol, $D$-galactose, and $D$-glucose diets all failed to induce mortality significantly different from the agar alone group, all resulting in $<9 \%$ mortality after $14 \mathrm{~d}$ (Fig. 18). As expected from our previous studies (Veillon et al. 2010), and coming into the results here, 2-deoxy- $D$-galactose induced mortality following day 10 and ultimately caused $85 \%$ cumulative mortality (Fig. 18).

myo-Inositol- $\left[2-{ }^{3} \mathrm{H}\right]$ Radiotracer Metabolic Study. The aqueous and lipid soluble layers from a Bligh and Dyer extraction (Bligh and Dyer 1959) of whole-body homogenates from termites fed myo-inositol- $\left[2-{ }^{3} \mathrm{H}\right]$, were assayed for radioactivity. A $100-\mu \mathrm{l}$ sample of the lipid soluble fraction contained low radiolabel and resulted in 40.8 wide counts per minute (CPM) and $17.6{ }^{3} \mathrm{H}$ CPM with 9.9 and $15.08 \%$ error, respectively. For comparison, a 100- $\mu$ l sample of the aqueous layer had 160.9 wide CPM and $131.6^{3} \mathrm{H}$ CPM with 4.99 and $5.51 \%$ error, respectively. A blank containing only liquid scintillation fluid resulted in 38.9 wide CPM and $14.4^{3} \mathrm{H} \mathrm{CPM}$ with 10.14 and $16.67 \%$ error, respectively, not significantly different from the concentrated lipid 


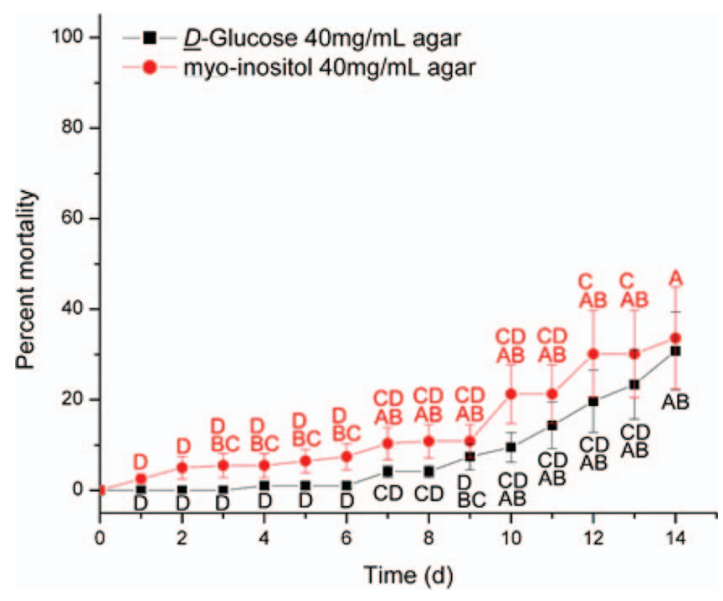

Fig. 17. Means $( \pm \mathrm{SE})$ of $C$. formosanus percent mortality following feeding on agar containing $40 \mathrm{mg} / \mathrm{ml}$ myo-inositol or $D$-glucose in no-choice assays with 20 workers $(n=3)$. Collection group B was used and the data were recorded for $14 \mathrm{~d}$. Means followed by the same letter are not significantly different $(P>0.05)$. The $F$ value for percent mortality is 4.84 . $P$ and df values are $<0.0001$ and 29,270 , respectively. (Online figure in color.)

layer. Radioactivity measured in 801 -ml fractions collected from chromatography of the aqueous layer on a silica gel column is shown in Fig. 19. The chromatograms show a single peak of radioactivity (Fig. 19), at the $R_{f}$ of myo-inositol on thin layer chromatography (TLC) (Fig. 20). These data support the conclusion that myo-inositol is not biochemically changed within $2 \mathrm{~d}$ following its consumption by C. formosanus.

\section{Discussion}

myo-Inositol and phytate are toxic to Formosan subterranean termites, when consuming cellulose. myoInositol significantly caused mortality when applied to food source filter paper discs at 640.8 and 1,281.7 $\mu \mathrm{g} / \mathrm{mm}^{3}$ in three independent bioassays (Figs. 4, 6, and 8). Phytate also significantly decreased feeding behavior at concentrations ranging from 320.4 to $1,281.7 \mu \mathrm{g} / \mathrm{mm}^{3}$ (Figs. 5-7).

C. formosanus termites have been reported to live in the absence of a food source for at least $12 \mathrm{~d}$ and closer to a month without significant mortality (Ibrahim et al. 2004), and in our experiments we have observed survival as long as $40 \mathrm{~d}$. Therefore, with the observation of lower cellulose consumption, starvation does not explain the observed mortality. At the present, we are uncertain if the sugars act as feeding deterrents or if decreased cellulose consumption is a symptom of an overall inositolor phytate-caused reduction in termite health.

Termites stripped of their protozoan symbionts, by rearing on sugar-supplemented agar diets, experience significant mortality when switched back to cellulosic food sources (Tanaka et al. 2006). Although myoinositol significantly reduces hindgut protozoan populations (Figs. 14 and 15), its toxicity to symbiont populations is a secondary effect. Interestingly, myo-
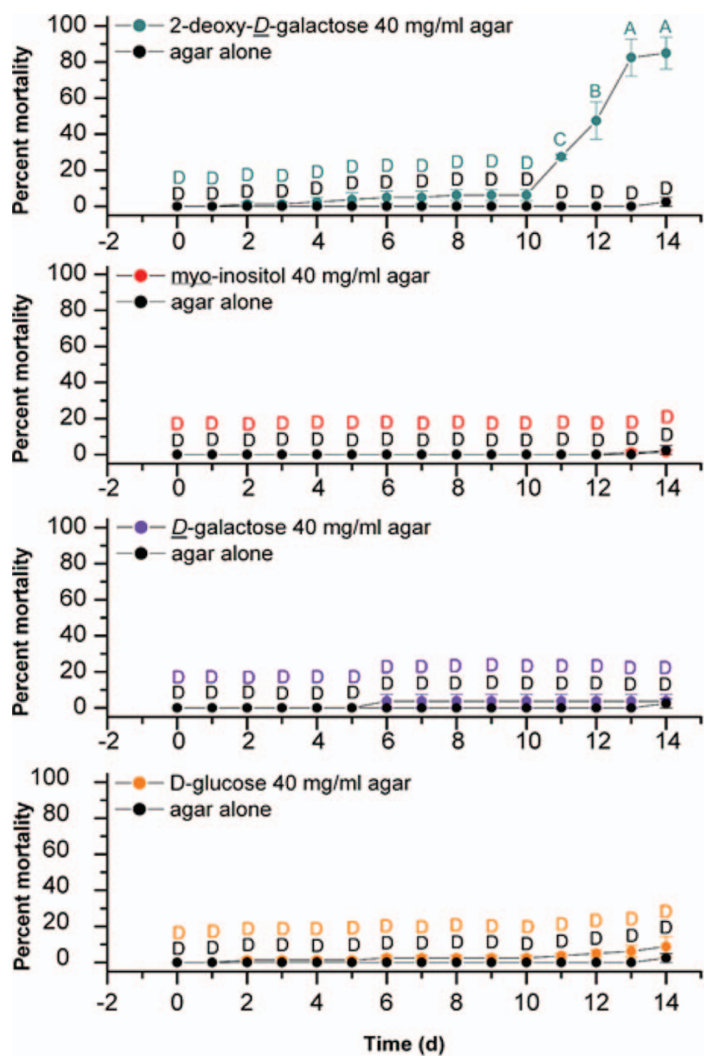

Fig. 18. Means ( $\pm \mathrm{SE}$ ) of C. formosanus percent mortality following feeding on agar or agar containing $40 \mathrm{mg} / \mathrm{ml} \mathrm{myo-}$ inositol, $D$-glucose, $D$-galactose or 2-deoxy- $D$-galactose in nochoice assays with 20 workers $(n=3)$. Collection group days was used and the data were recorded daily for $14 \mathrm{~d}$. Means followed by the same letter are not significantly different $(P>$ $0.05)$. The $F$ value for percent mortality is 28.11 . $P$ and $\mathrm{df}$ values are $<0.0001$ and 74,225 , respectively. (Online figure in color.)

inositol is not toxic when it is administered in an agar rather than cellulosic diet (Figs. 17 and 18), whereas 2-deoxy- $D$-galactose maintained its toxicity (Fig. 18).

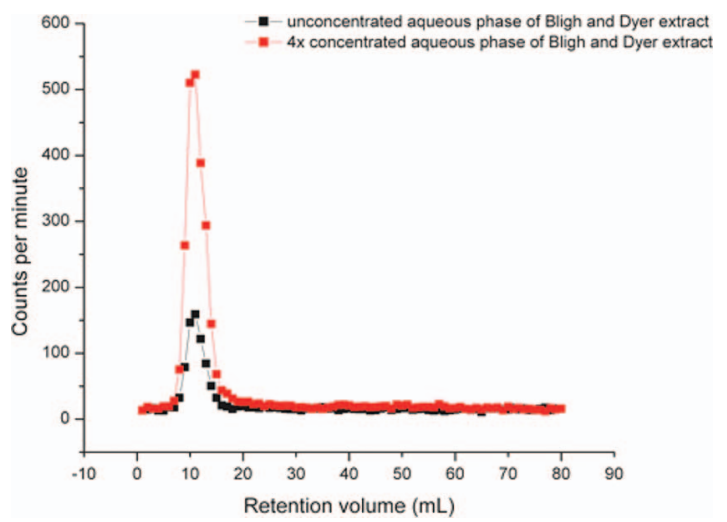

Fig. 19. Radioactivity detected in unconcentrated and $4 \times$ concentrated aqueous phase silica column fractions of Bligh and Dyer extract of C. formosanus homogenate. Twenty workers from collection group A were used. (Online figure in color.) 

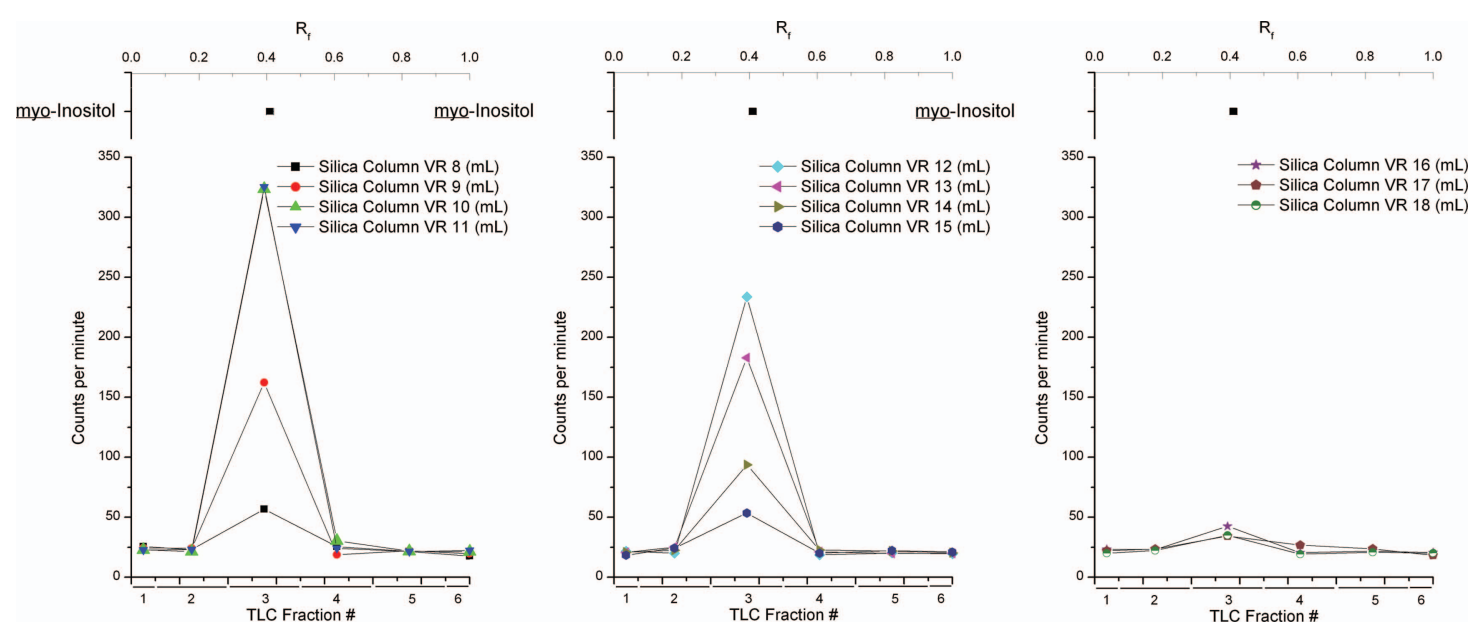

Fig. 20. Radioactivity detected in TLC fractions from silica column fractions found to contain tritium plotted against $R_{f}$ value of myo-inositol standard. (Online figure in color.)

Radiotracer studies show myo-inositol is not chemically changed following its consumption (Figs. 19 and 20) during the toxicity window, which may imply that it is either not effectively transported across the preor hindgut membrane or it is not incorporated in a salvage pathway. Future studies would focus on effects of administration of these compounds on metabolomics and gene expression to pursue the mechanism of action. Meanwhile, it appears that these compounds could be effective and inexpensive termiticides, innocuous to humans, and probably harmless to companion and food and fiber animals and the environment.

\section{References Cited}

Adams, L., and R. Boopathy. 2005. Isolation and characterization of enteric bacteria from the hindgut of Formosan termite. Bioresour. Technol. 96: 1592-1598.

Bligh, E. G., and W. J. Dyer. 1959. A rapid method for total lipid extraction and purification. Can. J. Biochem. Physiol. 37: 911-917.

Boga, H., and A. Brune. 2003. Hydrogen-dependent oxygen reduction by homoacetogenic bacteria isolated from termite guts. Appl. Environ. Microbiol. 69: 779-786.

Chen, L., C. Zhou, H. Yang, and M. F. Roberts. 2000. Inositol-1-phosphate Synthase from Archaeoglobus fulgidus Is a Class II Aldolase. Biochemistry 39: 12415-12423.

Cosgrove, D. J. 1980. Inositol phosphates, pp. 26-43. In D. J. Cosgrove (ed.), Their Chemistry, Biochemistry and Physiology. Elsevier Scientific Publishing Company, Amsterdam, The Netherlands.

Daiyasu, H., K. Kuma, T. Yokoi, H. Morii, Y. Koga, and H. Toh. 2005. A study of archaeal enzymes involved in polar lipid synthesis linking amino acid sequence information, genomic contexts and lipid composition. Archaea 1: $399-410$.

Donahue, T. F., and S. A. Henry. 1981. myo-Inositol-1-phosphate synthase. Characteristics of the enzyme and identification of its structural gene in yeast. J. Biol. Chem. 6: $7077-7085$.

Feng, M. G., C. L. Liu, J. H. Xu, and Q. Xu. 1998. Modeling and biological implication of time-dose-mortality data for the entomophthoralean fungus, Zoophthora anhuiensis, on the green peach aphid Myzus persicae. J. Invertebr. Pathol. 72: 246-251.

Grace, J. K., D. M. Ewart, and C. Tome. 1996. Termite resistance of wood species grown in Hawaii. For. Prod. J. 46: $57-60$.

Hardy, T. 1988. The condo eaters. BioScience 38: 662-664.

Henderson, G. 1996. Alate Production, flight phenology, and sex-ratio in Coptotermes formosanus Shiraki, an Introduced Subterranean Termite in New Orleans, Louisiana. Sociobiology 28: 319-326.

Henderson, G. 2001. Practical consideration of the Formosan subterranean termite in Louisiana: a 50-year-old problem. Sociobiology 37: 281-392.

Henderson, G., and C. Dunaway. 1999. Keeping Formosan termites away from underground telephone lines. LA. Agric. 42: 5-7.

Ibrahim, S. A., G. Henderson, B.C.R. Zhu, H. Fei, and R. A. Laine. 2004. Toxicity and Behavioral Effects of Nootkatone, 1,10-Dihydronootkatone, and Tetrahydronootkatone to the Formosan Subterranean Termite (Isoptera: Rhinotermitidae). J. Econ. Entomol. 97: 102-111.

Itakura, S., H. Tanaka, and A. Enoki. 1997. Distribution of cellulases, glucose and related substances in the body of Coptotermes formosanus. Mater. Org. (Berl.) 31: 17-29.

Lax, A. R., and W.L.A. Osbrink. 2003. United States Department of Agriculture - Agriculture Research Service research on targeted management of the Formosan subterranean termite Coptotermes formosanus Shiraki (Isoptera: Rhinotermitidae). Pest Manage. Sci. 59: 788-800.

Leadbetter, J., and J. Breznak. 1996. Physiological ecology of Methanobrevibacter cuticularis sp. nov. and Methanobrevibacter curvatus sp. nov., isolated from the hindgut of the termite Reticulitermes flavipes. Appl. Environ. Microbiol. 62: 3620-3631.

Levin, G. V., and L. R. Zehner 1992. Inventors; biospherics incorporated, assignee. Nov 24. Method For Killing Pests. U.S. patent 5,166,193.

Loewus, F. A., and P.P.N. Murthy. 2000. myo-Inositol metabolism in plants. Plant Sci. 150: 1-19.

Maistrello, L., G. Henderson, and R. A. Laine. 2002. Comparative effects of vetiver oil, nootkatone and disodium octaborate tetrahydrate on Coptotermes formosanus and its symbiotic fauna. Pest Manage. Sci. 59: 58-68. 
Majumder, A. L., A. Chatterjee, K. G. Dastidar, and M. Majee. 2003a. Diversification and evolution of L-myo-inositol 1-phosphate synthase. FEBS Lett. 553: 3-10.

Mannesmann, R. 1972. Relationship between different wood species as a termite food source and the reproduction rate of termite symbionts. Z. Angew. Entomol. 72: 116-128.

Mertins, J. W., H. C. Coppel, J. A. Breznak, and W. J. Brill. 1973. Demonstration of nitrogen fixation in termites. Univ. Wis. For. Res. Notes 168: 4.

Messenger, M. T., R. T. Scheffrahn, and N. Y. Su. 2000. First report of Incisitermes minor (Isoptera: Kalotermitidae) in Louisiana. Fla. Entomol. 83: 92-93.

Messenger,M. T., N. Y.Su, and R. H.Scheffrahn. 2002. Current distribution of the Formosan subterranean termite and other termite species (Isoptera: Rhinotermitidae, Kalotermitidae) in Louisiana. Fla. Entomol. 85: 580-587.

Nakashima, K., H. Watanabe, H. Saitoh, G. Tokuda, and J. I. Azuma. 2002. Dual cellulose-digesting system of the wood-feeding termite, Coptotermes formosanus Shiraki. Insect Biochem. Mol. Biol. 32: 777-784.

Noda, S., T. Iida, O. Kitade, H. Nakajima, T. Kudo, and M. Ohkuma. 2005. Endosymbiotic Bacteroidales bacteria of the flagellated protist Pseudotrichonympha grassii in the gut of the termite Coptotermes formosanus. Appl. Environ. Microbiol. 71: 8811-8817.

Noda, S., O. Kitade, T. Inoue, M. Kawai, M. Kanuka, K. Hiroshima, Y. Hongoh, R. Constantino, V. Uys, J. Zhong, et al. 2007. Cospeciation in the triplex symbiosis of termite gut protists (Pseudotrichonympha spp.), their hosts, and their bacterial endosymbionts. Mol. Ecol. 16: 12571266.

Nowierski, R. M., Z. Zeng, S. Jaronski, F. Delgado, and W. Swearingen. 1996. Analysis and modeling of time-dosemortality of Melanoplus sanguinipes, Locusta migratoria migratorioides, and Schistocerca gregaria (Orthoptera: Acrididae) from Beauveria, Metarhizium, and Paecilomyces isolates from Madagascar. J. Invertebr. Pathol. 67: 236-252.

Osbrink, W.L.A., W. D. Woodson, and A. R. Lax. 1999. Populations of Formosan subterranean termite, Coptotermes formosanus (Isoptera: Rhinotermitidae), established in living urban trees in New Orleans, Louisiana, USA, pp. 341-345. In Proceedings, 3rd International Conference on Urban Pests, 1999, Prague, Czech Republic. Graficke zavocy, Hronov, Czech Republic.

Raboy, V. 1997. Accumulation andstorage of phosphate and minerals, pp. 441-477. In B. A. Larkins and I. K. Vasil. (eds.), Cellular and Molecular Biology of Plant Seed Development. Kluwer Academic Publishers, Dordrecht, The Netherlands.

Robertson, J. L., and H. K. Preisler. 1992. Pesticide Bioassays with Arthropods. CRC, Boca Raton, FL

SAS Institute. 2002. SAS/STAT user's guide, version 9.1. SAS Institute, Cary, NC.

Sasakawa, N., M. Sharif, and M. R. Hanley. 1995. Metabolism and biological activities of inositol pentakisphosphate and inositol hexakisphosphate. Biochem. Pharmacol. 50: 137146.

Schmitt, W. D., and A. Brune. 1999. Hydrogen profiles and localization of methanogenic activities in the highly compartmentalized hindgut of soil-feeding higher termites (Cubitermes spp.). Appl. Environ. Microbiol. 65: 44904496.

Smith, W. R., T. L. Amburgey, G. Henderson, and D. R. Ring. 2004. Facility for conducting field tests on Coptotermes formosanus at Louisiana State University Agricultural Center. For. Prod. J. 54: 26-28.

Spherix. 2002. Spherix Achieves Nationwide Flycracker Distribution. (http://www.infospherix.com/PressRelease/ pr052902.html\#).

Spink, W. T. 1967. The Formosan subterranean termite in Louisiana, Louisiana State University Circ. 89. Louisiana State University, Baton Rouge, LA.

Stieglitz, K. A., H. Yang, M. F. Roberts, and B. Stec. 2005. Reaching for mechanistic consensus across life kingdoms: structure and insights into catalysis of the myo-inositol1-phosphate synthase (mIPS) from Archaeoglobus fulgidus. Biochemistry 44: 213-224.

Stieglitz, K. A., M. F. Roberts, W. Li, and B. Stec. 2007. Crystal structure of the tetrameric inositol-1-phosphate phosphatase (TM1415) from the hyperthermophile, Thermotoga maritima. FEBS J. 274: 2461-2469.

Su, N. Y. 2003. Overview of the global distribution and control of the Formosan subterranean termite. Sociobiology 41: 7-15.

Tanaka, H., H. Aoyagi, S. Shina, Y. Dodo, T. Yoshimura, R. Nakamura, and H. Uchiyama. 2006. Influence of the diet components on the symbiotic microorganisms community in hingut of Coptotermes formosanus Shiraki. Appl. Microbiol. Biotechnol. 71: 907-917.

Tholen, A., and A. Brune. 1999. Localization and in situ activities of homoacetogenic bacteria in highly compartmentalized hindgut of soil-feeding higher termite $(\mathrm{Cu}$ bitermes spp.). Appl. Environ. Microbiol. 65: 4497-4505.

Veillon, L., S. Muniruzzaman, G. Henderson, and R. A. Laine. 2010. Toxic Effects of 2-Deoxy-D-Galactose on Coptotermes formosanus (Isoptera: Rhinotermitidae) and Symbionts. J. Econ. Entomol. 103: 1647-1656.

Watanabe, H., K. Nakashima, H. Salto, and M. Slaytor. 2002. New endo-b-1,4-glucanases from the parabasalian symbionts, Pseudotrichonympha grassii and Holomastigotoides mirabile of Coptotermes termites. Cell. Mol. Life Sci. 59: 1983-1992.

Woodson, W. D., B. A. Wiltz, and A. R. Lax. 2001. Current distribution of the Formosan subterranean termite (Isoptera: Rhinotermitidae) in the United States. Sociobiology 37: 661-671.

Yoshimura, T. 1995. Contribution of the protozoan fauna to nutritional physiology of the lower termite, Coptotermes formosanus Shiraki (Isoptera: Rhinotermitidae). Wood Res. 82: 68-129.

Yoshimura, T., J. Azuma, K. Tsunoda, and M. Takahashi. 1993a. Cellulose metabolism of the symbiotic protozoa in termite, Coptotermes formosanus Shiraki (Isoptera: Rhinotermitidae). I. effect of degree of polymerization of cellulose. Mokuzai Gakkaishi. 39: 221-226.

Yoshimura, T., J. Azuma, K. Tsunoda, and M. Takahashi. 1993b. Cellulose metabolism of the symbiotic protozoa in termite, Coptotermes formosanus Shiraki (Isoptera: Rhinotermitidae). II. selective defaunation of protozoa and its effect on cellulose metabolism. Mokuzai Gakkaishi. 39: 227-230.

Zhu, B.C.R., G. Henderson, and R. A. Laine. 2005. A screening method for inhibitors against Formosan subterranean termite Beta-Glucosidases in vivo. J. Econ. Entomol. 98: 41-46.

Received 14 July 2013; accepted 4 July 2014. 